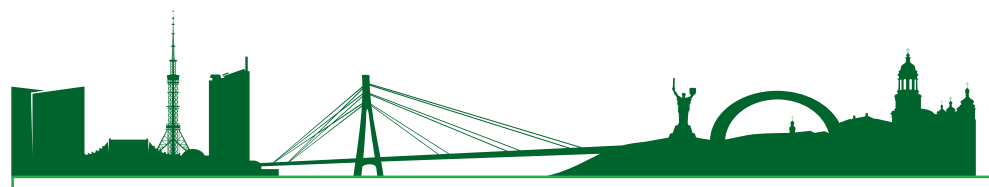

УдК 620.91: 697.1

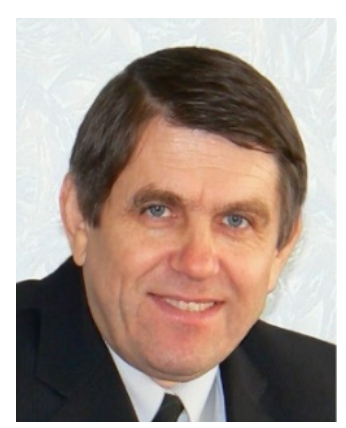

ТИМОФЕЕВ М.В.

Канд. технічних наук, доц., зав. Науково-технічного центру 3 питань енергоефективності та енергозбереження у сфері будівництва, ДП «Державний науково-дослідний інститут будівельних конструкцій»,

м. Київ, Україна,

e-mail:tymofieiev@ndibk.gov.ua, тел.: +38 (050) 239-28-37, ORCID: 0000-0001-9234-6567

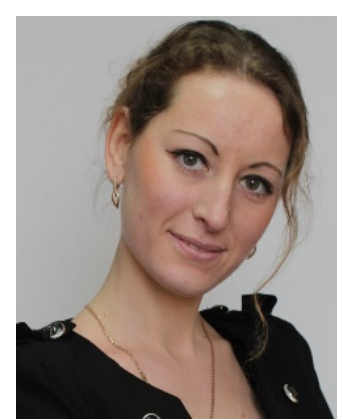

\section{БIЛОУС I.Ю.}

Канд. технічних наук, асист., Національний технічний університет «Київський політехнічний інститут ім. Ігоря Сікорського», м. Київ, Україна,

e-mail: biloys_inna@ukr.net, тел.: + 38 (068)-0̄15-15-63,

ORCID: 0000-0002-6640-103X

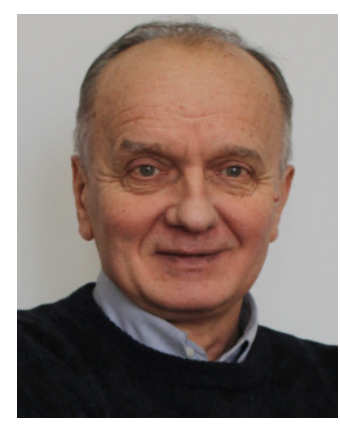

ДЕШКО В.І.

Д-р технічних наук, проф., зав. каф., Національний технічний університет України «Київський політехнічний інститут ім. Ігоря Сікорського»,

м. Київ, Україна, e-mail: te@kpi.ua,

тел.: + 38 (044)-204-82-50, ORCID: 0000-0002-8218-3933

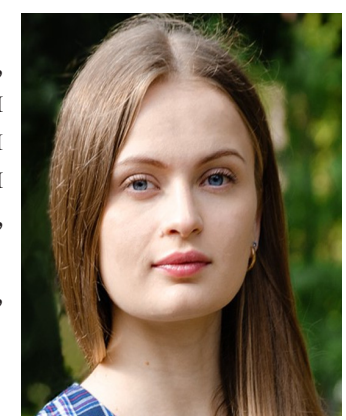

ГЕТМАНЧУК Г.О.

Магістр, Національний технічний університет України «Київський політехнічний інститут ім. Ігоря Сікорського»,

м. Київ, Україна, e-mail:hetmanchuk.anna@gmail.com, тел.: +38 (0 66) 0692638 , ORCID: 0000-0003-1655-8642

\title{
РОЗРАХУНОК ПОГОДИННОЇ ПРИРОДНОЇ КРАТНОСТІ ПОВІТРООБМІНУ ТА ЇЇ ВПЛИВ НА ЕНЕРГОПОТРЕБУ БУДІВЕАЬ В ДИНАМІЧНИХ СІТКОВИХ МОДЕАЯХ
}

\section{АНОТАЦІЯ}

На енергетичні характеристики будівель впливає велика кількість як зовнішніх, так i внутрішніх факторів. Одним з найбільш впливових параметрів є кратність повітрообміну, що має природну (інфільтрація) та механічну природу. Природна складова кратності повітрообміну залежить від великої кількості факторів, та ії значення різне для різних приміщень при однакових теплофізичних властивостях огороджень.

В роботі представлені результати математичного моделювання погодинного графіка енергопотреби будівлі для базового рівня при нормативному значенні кратності повітрообміну, а також при розрахованому значенні природної складової кратності повітрообміну, що змінюється відповідно до погодних умов. Результати оцінки визначили, що розраховане значення природної складової кратності повітрообміну для приміщень 3 сучасними огородженнями не перевищує 0,25 год ${ }^{-1}$. Тому застосування цих значень природної кратності повітрообміну призводить до зменшення енергопотреби до 50\%, в порівнянні 3 базовою лінією.
В приміщенні потрібно забезпечувати нормативну кратність повітрообміну, що повинно компенсуватися провітрюванням або механічною складовою повітрообміну. Врахування фактичної природної кратності природного повітрообміну в приміщеннях змінної зайнятості уточнює визначення рівня ефективності енергозберігаючих заходів з термомодернізації, а також визначає складову, що повинна забезпечуватися механічною вентиляцією, а отже і може бути утилізована в теплообмінниках рекуперативного типу.

КЛЮЧОВІ СЛОВА: енергопотреба, динамічні сіткові моделі, кратність повітрообміну, інфільтрація.

\section{РАСЧЕТ ПОЧАСОВОЙ ЕСТЕСТВЕННОЙ КРАТНОСТИ ВОЗДУХООБМЕНА И ЕЕ ВАИЯНИЕ НА ЭНЕРГОПОТРЕБНОСТЬ ЗДАНИЙ В ДИНАМИЧЕСКИХ МОДЕАЯХ}

ТИМОФЕЕВ Н.В. Канд. технических наук, доц., зав. Научно-техническим центром по вопросам энергоеффективности и энергосбережения в сфере строительства, ГП «Государственный 


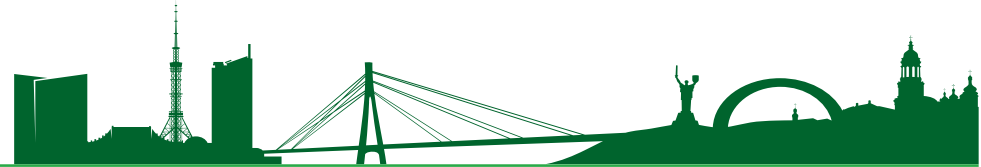

научно-исследовательский институт строительных конструкций»,

г. Киев, Украина,

e-mail: tymofieiev@ndibk.gov.ua,

тел.: +38 (050) 239-28-37,

ORCID: 0000-0001-9234-6567

ДЕШКО В.I. Д-р технических наук, проф., зав. каф., Национальный технический университет Украины «Киевский политехнический институт им. Игоря Сикорского»,

г. Киев, Украина,

e-mail: te@kpi.ua,

тел.: + 38 (044)-204-82-50,

ORCID: 0000-0002-8218-3933

БЕЛОУС И.Ю. Канд. технических наук, ассистент, Национальный технический университет Украины «Киевский политехнический институт им. Игоря Сикорского»,

г. Киев, Украина,

e-mail: biloys_inna@ukr.net,

тел.: + 38 (068)-015-15-63,

ORCID: 0000-0002-6640-103X

ГЕТМАНЧУК А.А. Магистр, Национальный технический университет Украины «Киевский политехнический институт им. Игоря Сикорского»,

г. Киев, Украина,

e-mail: hetmanchuk.anna@gmail.com,

тел.: + 38 (066) 0692638 ,

ORCID: 0000-0003-1655-8642

\section{АННОТАЦИЯ}

На энергетические характеристики зданий влияет большое число как внешних, так и внутренних факторов. Одним из наиболее влиятельных параметров является кратность воздухообмена, которая имеет естественную (инфильтрация) и механическую природу. Естественная составляющая кратности воздухообмена зависит от большого числа факторов и ее значение отличается для разных помещений при одинаковых теплофизических свойствах ограждений.

В работе представлены результаты математического моделирования почасового графика энергопотребности здания для базового уровня при нормативном значении кратности воздухообмена, а также при расчетном значении природной составляющей кратности воздухообмена, которая изменяется в соответствии с природными условиями. Результаты оценки определили, что расчетное значение естественной составляющей кратности воздухообмена для помещений с современными ограждениями не превышает 0,25 ч $^{-1}$. Поэтому применение этих значений кратности воздухообмена приводит к уменьшению энергопотребности до 50\%, по сравнению с базовой линией.

В помещении нужно обеспечивать нормативную кратность воздухообмена, что должно компенсироваться механической составляющей воздухообмена. Учет фактической кратности есте- ственного воздухообмена в помещениях переменной занятости улучшает привлекательность энергосберегающих мероприятий по термомодернизации, а также определяет составляющую, которая должна обеспечиваться механической вентиляцией, а, следовательно, и может быть утилизирована в теплообменники рекуперативного типа.

КЛЮЧЕВЫЕ CЛOBA: энергопотребность, динамические сетевые модели, кратность воздухообмена, инфильтрация.

\section{CALCULATION OF THE NATURAL RATE OF AIR EXCHANGE PER HOUR AND ITS INFLUENCE ON THE ENERGY NEEDS OF BUILDINGS IN NET DYNAMIC MODELS}

TYMOFEYEV M.V. PhD, Ass. Prof., Head of the Scientific and Technical Center for Energy Efficiency and Energy Saving in the Construction, SE «The State Research Institute of Building Constructions», Kyiv, Ukraine,

e-mail: tymofieiev@ndibk.gov.ua, tel.: +38 (050) 239-28-37,

ORCID: 0000-0001-9234-6567

DESHKO V.I. Dr. Prof., Head of the Department, National Technical University of Ukraine «Igor Sikorsky Kyiv Polytechnic Institute»,

Kyiv, Ukraine,

e-mail: te@kpi.ua,

tel.:+38 (044)-204-82-50,

ORCID: 0000-0002-8218-3933

BILOUS I.Yu. PhD, Ass., National Technical University of Ukraine «Igor Sikorsky Kyiv Polytechnic Institute»,

Kyiv, Ukraine,

e-mail: biloys_inna@ukr.net,

tel.:+38 (068)-015-15-63,

ORCID: 0000-0002-6640-103X

HETMANCHUK H.O. Master student, National Technical University of Ukraine «Igor Sikorsky Kyiv Polytechnic Institute»,

Kyiv, Ukraine,

e-mail: hetmanchuk.anna@gmail.com,

tel.: +38 (0 66) 0692638 ,

ORCID: 0000-0003-1655-8642

\section{ABSTRACT}

The buildings energy characteristics are influenced by a large number of external and internal factors. One of the most influential parameters is the air exchange rate, which has a natural (infiltration) and mechanical nature. The air exchange rate natural component depends on a large number of factors and its value varies for different premises with the same envelope thermophysical properties.

The paper presents the results of the mathematical modeling of the building energy need per hour schedule for the base level with the standard value of the air exchange rate, as well at the calculated value 


\section{MLA}

of the air exchange rate natural component varying according to natural conditions. The results of rating determined that for premises with modern envelopes the calculated value of the air exchange rate natural component does not exceed $0.25 \mathrm{~h}^{-1}$. Therefore, the application of those values of the air exchange rate results in the energy need decrease up to $50 \%$, compared with the baseline.

In the room it is necessary to ensure the standard multiplicity of air exchange, which must be offset by the mechanical component of air exchange. Taking into account the actual rate of natural air exchange in the premises of the variable occupancy improves the attractiveness of the thermo-modernization with energy-saving measures, as well as determines the component that must be provided by mechanical ventilation and, therefore, can be utilized in the recuperative heat exchangers as well.

KEY WORDS: Energy need, dynamic net models, air exchange rate, infiltration.

\section{ВСТУП}

На функціонування будівель витрачається біля $40 \%$ енергоносіїв в усьому світі, левова частка яких складають витрати теплової енергії. Підвищення енергоефективності існуючого будівельного фонду для України є актуальною задачею, зважаючи на енергетичну залежність нашої держави.

Теплові та енергетичні характеристики будівель залежать від великої кількості зовнішніх і внутрішніх факторів [1-3], серед яких найбільш впливовими є теплофізичні властивості оболонки, геометрія, теплонадходження від сонця та додаткові внутрішні, опалення, повітрообмін та особливості експлуатації. Саме ці показники впливають на базовий рівень енергоспоживання.

\section{АНАЛIЗ ОСТАННІХ ДОСАІДЖЕНЬ I ПУБАІКАЦІЙ}

Відповідно до стандарту [4] щодо рекомендацій першочерговості впровадження енергозберігаючих заходів, основна увага приділена заходам 3 термосанації оболонки будівлі. Після впровадження заходів з термосанації (перший етап), вентиляційна складова теплових навантажень у житлових і комерційних будівлях може становити від 25 до 50\% [5, 6, 3]. Зменшення цієї складової є другим етапом впровадження енергозберігаючих заходів в Україні.

Проведені в останні роки дослідження значну увагу приділяють питанням повітрообміну [7-9]. Дослідження [10] показали, що найбільш впливовим параметром на енергобаланс будівлі $є$ кратність повітрообміну. Наприклад, стаття витрати на інфільтрацію у Франції складає 15\% [11]. У США дослідники приходять до висновку, що дана складова сягає 33\% [12].

В розрахунках базового рівня енергоспоживання ця величина приймається відповідно до нор- мативних значень [13], а іï фактичне значення важко визначити експериментально, враховуючи, що природна складова цього параметру має динамічну природу.

МЕТОЮ РОБОТИ є підвищення ефективності управління використанням енергії на основі деталізації експлуатаційних показників природної кратності повітрообміну із застосуванням динамічних сіткових моделей для визначення енергопотреби будівлі.

Методичну основу проведеного наукового дослідження склали: методи математичного та імітаційного моделювання, системний підхід з урахуванням температурно-погодних та експлуатаційних факторів.

\section{РЕЗУЛЬТАТИ ДОСАІДЖЕНЬ}

Тенденції розвитку математичних моделей для визначення енергетичного стану будівлі спрямовані на зменшення часових інтервалів та в напрямку визначення локалізації характеристик системи і впливових факторів [14, 6, 2].

Для дослідження енергетичних характеристик будівлі було розглянуто групу репрезентативних кімнат південної та північної орієнтації для теплофізичних властивостей огороджень, характерних для масової забудови 3 двокамерними склопакетами в ПВХ-профілях з опором повітропроникності $2,7 \quad\left(\mathrm{~m}^{2} \cdot\right.$ год $\left.\cdot \mathrm{\Pi a}^{2 / 3}\right) /$ кг. Будівля має 6 поверхів, де підтримується постійна температура повітря в приміщеннях $18^{\circ} \mathrm{C}$. На основі обраних репрезентативних приміщень (на 1, 3 та 6 поверхах північної та південної орієнтації) створено динамічні сіткові моделі 5R1C (за стандартами ДСТУ Б EN ISO 13790:2011 [15] та EN ISO 13786:2008 [16]). В роботі дослідження проведені для кліматичних умов м. Києва за даними міжнародного кліматичного погодинного файлу IWEC [17].

На основі динамічної сіткової моделі 5R1C проведено дослідження впливу зміни кратності повітрообміну на енергопотребу будівлі.

\section{РОЗРАХУНОК ПРИРОДНОЇ СКААДОВОЇ КРАТНОСТІ ПОВІТРООБМІНУ В ДИНАМІЦІ МІНАИВОСТІ УМОВ ЗОВНІШНЬОГО СЕРЕ- ДОВИЩА}

Зазвичай, у математичних моделях для визначення енергопотреби будівель вентиляційна складова (повітрообмін) задається через значення кратності повітрообміну. Але навіть при однакових, 3 точки зору повітропроникності, конструкціях вікон, природнім чином в приміщення потрапляє різна кількість повітря, що пов'язано з рядом факторів, як зовнішніх, так i внутрішніх: швидкість, напрям вітру, поверховість, опір повітропроникності, температури повітря в приміщенні та зовні. В роботі використано узагальнення методик визначення 


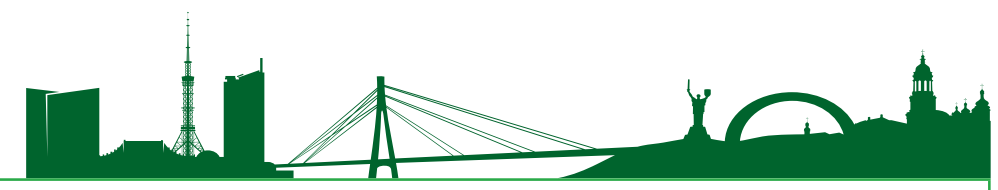

кратності повітрообміну, заснованих на визначенні різниці тисків, наведених в дослідженнях [3, 18, 19] та за підходами ASHRAE [20-22]. Різниця тисків в будівлі створюється трьома різними механізмами: ефект стека (stack effect), тиску вітру, примусовий тиск вентилятора механічної вентиляції (рис.1), - як їх сума.

Стек ефект, що створюється різницею густин між теплим і холодним повітрям, визначається за (1) [19]:

$$
\Delta P_{s}=3456 \cdot z\left(\frac{1}{T_{e}}-\frac{1}{T_{i}}\right),
$$

де Те, Ті - температура зовнішнього та внутрішнього повітря, відповідно, К; z - висота від опорної точки, м; $\mathrm{z}=0$, обраної за нейтральним рівнем тиску (neutral pressure level - NPL) на середньому поверсі будівлі.

Вітряний тиск створюється, коли потік повітря потрапляє на перешкоду (вираз (2)):

$$
\Delta P_{w} \in \frac{\rho U_{m e t}^{2}}{2} C_{h} \quad{ }_{p}(\theta),
$$

де $\Delta P_{w}$ - вітряний перепад тиску, Па; $\rho$ - густина навколишнього середовища, кг/м м $^{3} U_{\text {met }}$ - швидкість вітруза метеоданими найближчої метеостанції, м/с; $C_{h}$ - коефіцієнт тиску вітру, що враховує поверховість; $C_{p}(\theta)$ коефіцієнт, що враховує особливість напрямку вітру.

В роботі розраховано природну складову кратності повітрообміну, що обумовлена механізмом (1, 2). Для розглянутого типу віконних конструкцій розраховані за $(1,2)$ значення природної кратності повітрообміну знаходяться в діапазоні від -0,25 до 0, 25 год - $^{-1}$ Найбільший діапазон коливань цієї величини спостерігається для місяця січня.

На першому поверсі переважно спостерігається явище інфільтрації (приплив свіжого повітря природнім чином через нещільності у віконних конструкціях), на середньому третьому поверсі по всіх місяцях кратність у середньому близька до нуля, що пов'язано із NPL будівлі (стек ефект), на шостому поверсі спостерігається ексфільтрація, якій відповідають від'ємні значення кратності.

На рис. 2 наведено середне за опалювальний сезон значення природної складової кратності повітрообміну для основних та проміжних орієнтацій приміщень за сторонами світу (на прикладі 1 поверху).

Для міста Києва типовим напрямком вітру є північний та північно-західний, що призво-

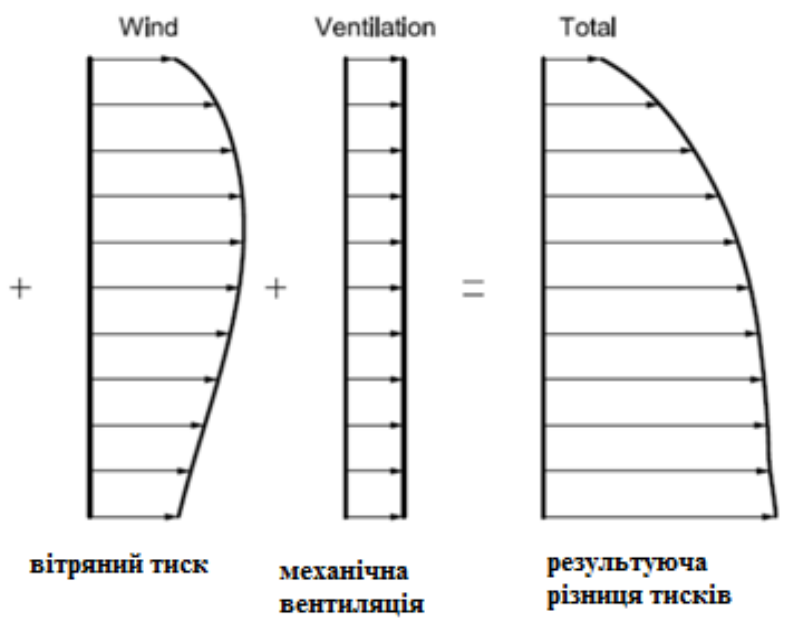

підсумування профілів
по висоті будівлі [7]

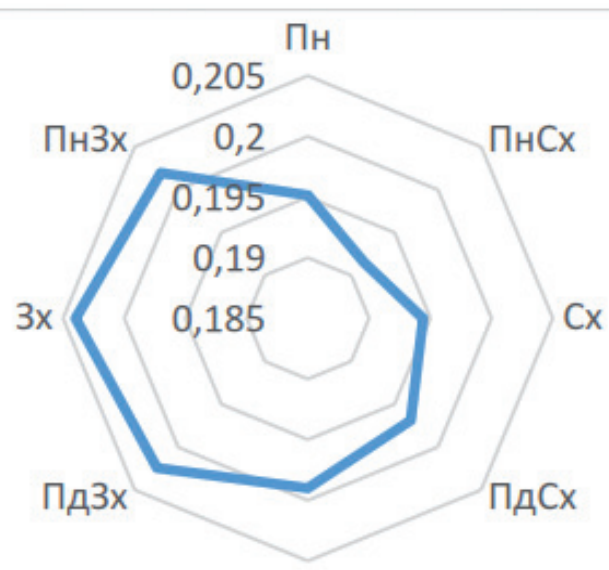

Пд

Рис. 2. Середня за опалювальний сезон природна овітрообміну приміщення першого поверху для різних орієнтацій, год-1

дить до менших значень природної кратності повітрообміну для приміщень відповідних орієнтацій (рис. 2), що пояснюється найменшим значенням коефіцієнту $C_{p}(\theta)$.

3 балансу природної кратності повітрообміну розглянутої шестиповерхової будівлі випливає, що кількість інфільтрованого та ексфільтрованого повітря однакова, тобто для розглянутого періоду, сума природних кратностей повітрообміну дорівнюе нулю. На рис. 3 наведено зміну середньодобової природної кратності повітрообміну для репрезентативних приміщень північної орієнтації.

РОЗРАХУНОК ЕНЕРГОПОТРЕБИ ТА АНАЛІЗ КОАИВАНЬ НАВАНТАЖЕННЯ ПРИ ЗМІНІ ФАКТИЧНОГО РІВНЯ ПРИРОДНОЇ КРАТНОСТI ПОВIТРООБМІНУ

Відповідно до моделі 5R1C (динамічна сіткова модель кімнати, п'ять опорів, одна ємність) енергопотреба на опалення знаходиться за розра- 

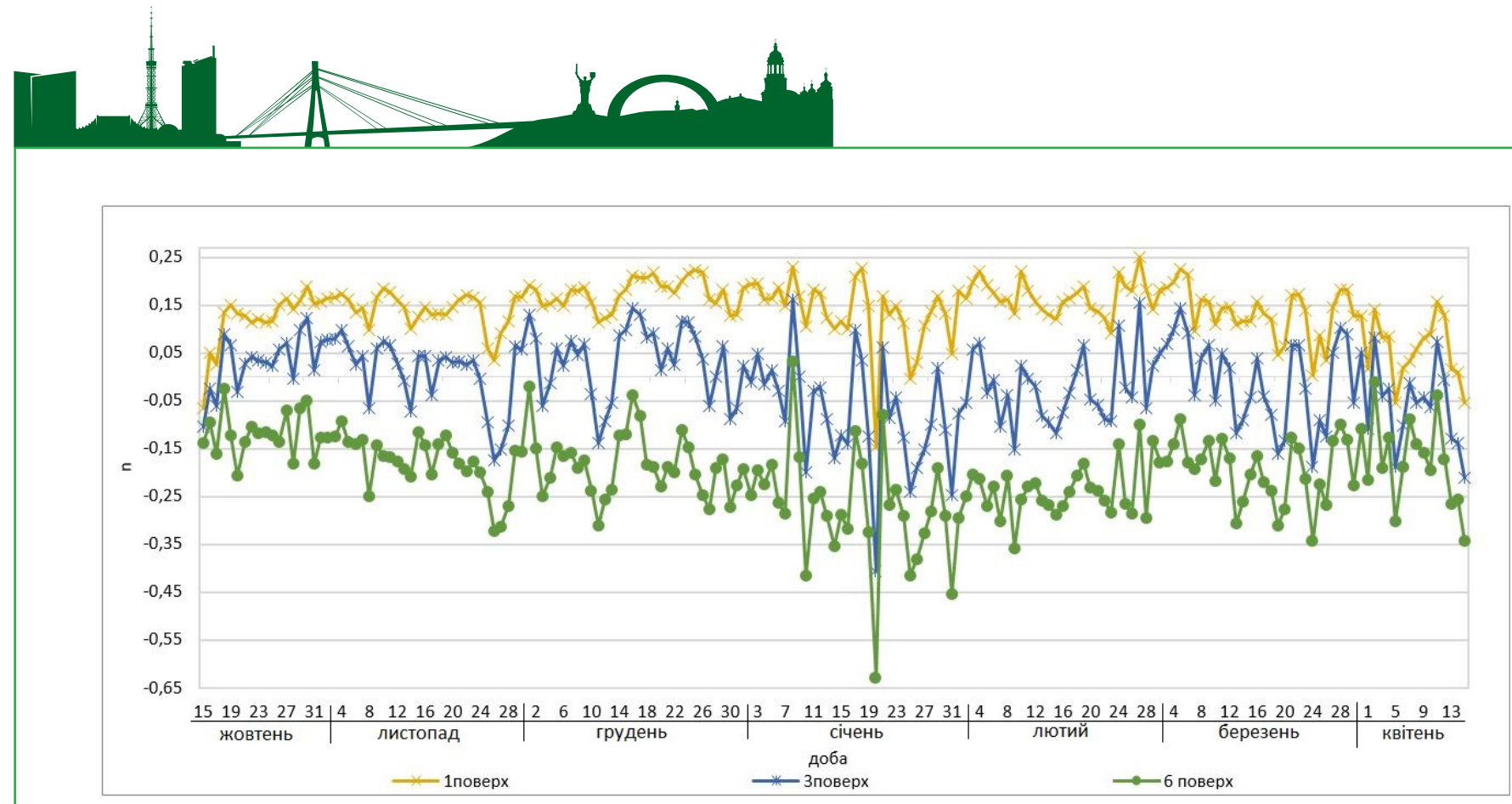

Рис. 3. Розрахована зміна середньодобової кратності повітрообміну для північної орієнтації та кліматичних даних (з файлу IWEC) протягом опалювального періоду

хунковим значення потужності опалення для кожної години, що повинна бути надана до вузла температури внутрішнього повітря (Өair), для підтримування певної заданої температури. Схема реалізації методу наведена на рис. 4.

Графік енергопотреби при $\mathrm{n}=\mathrm{const}$ обрано за базовий рівень і від нього розраховується економія впровадження енергозберігаючих заходів. При використанні розрахованих значень природної складової кратності повітрообміну, за рахунок природньої вентиляції (нещільностей у сучасних віконних конструкціях) надходження свіжого повітря в зону кімнати i втрати тепла значно змінюються під дією природних чинників, а відповідно змінюється і енергопотреба будівлі.

Проведено співставлення відмінності питомої енергопотреби розрахованої для $\mathrm{n}=1$ год-1 (нормативна кратність повітрообміну) та розрахованого значення природної складової $\quad(\mathrm{n}=\mathrm{var})$. Відмінність енергопотреби для опалювального періоду може становити понад 50\%, в порівнянні 3 базовою лінією. Наприклад, на першому поверсі приміщення Пн орієнтації відмінність 50\%, на Пд - 65\%.

При визначеному рівні природного повітрообміну для розглянутого типу вікон (опір повітропроникності), система опалення приміщень на південь може бути відімкнена в періоди міжсезоння (жовтень, квітень), тобто вікно працюе як пасивна система опалення.
В холодний період року енергопотреба, розрахована для значень кратності повітрообміну нормативних та відповідно до змінних природних умов (природної кратності повітрообміну), відрізняється до 50\%, а для періоду міжсезоння - до $75 \%$.

На рис. 5 наведено зміну навантаження на систему опалення для нормативних (1) та розрахованих (2) значень природної кратності повітрообміну для приміщення, орієнтованого на північ (а) та південь (б), розташованих на першому поверсі.

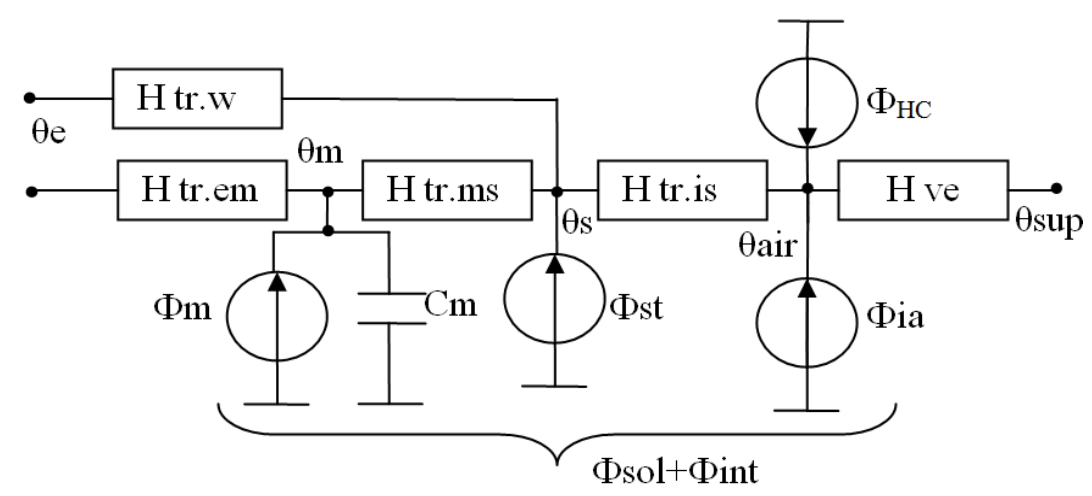

Рис. 4. Динамічна сіткова модель кімнати, п'ять опорів, одна ємність (5R1C) [6], де $\theta_{\text {air }}, \theta_{s}, \theta_{e}, \theta_{m}, \theta_{\text {sup }}$ - температура повітря, внутрішніх поверхонь, зовнішнього середовища, масиву непрозорих огороджень, припливного повітря, відповідно, ${ }^{\circ} \mathrm{C} ; \Phi_{m}, \Phi_{s b}$ $\Phi_{i a}$ - додаткові теплонадходження від сонця $\left(\Phi_{\text {sol }}\right)$ та внутрішні $\left(\Phi_{\text {int }}\right)$, що розподіляються між вузлом повітря, поверхнею внутрішніх огороджень та масивом стін, $B_{m} ; \Phi_{H C}-$ тепловий потік від системи опалення, $B_{m}$; $C_{m}$ - внутрішня теплоємність непрозорих елементів огороджень, Дж/К; $H_{t r w}, H_{t r e m}, H_{t r m s}, H_{t r i s}, \mathrm{H}_{v e}-$ сполучена провідність між вузлами температури, що характеризує трансмісійні втрати через оболонку будівлі та вентиляцію, Вт/К 


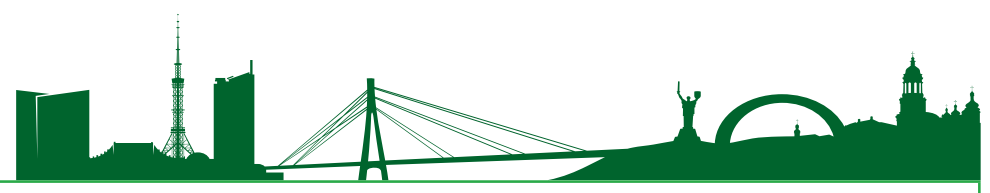

a)

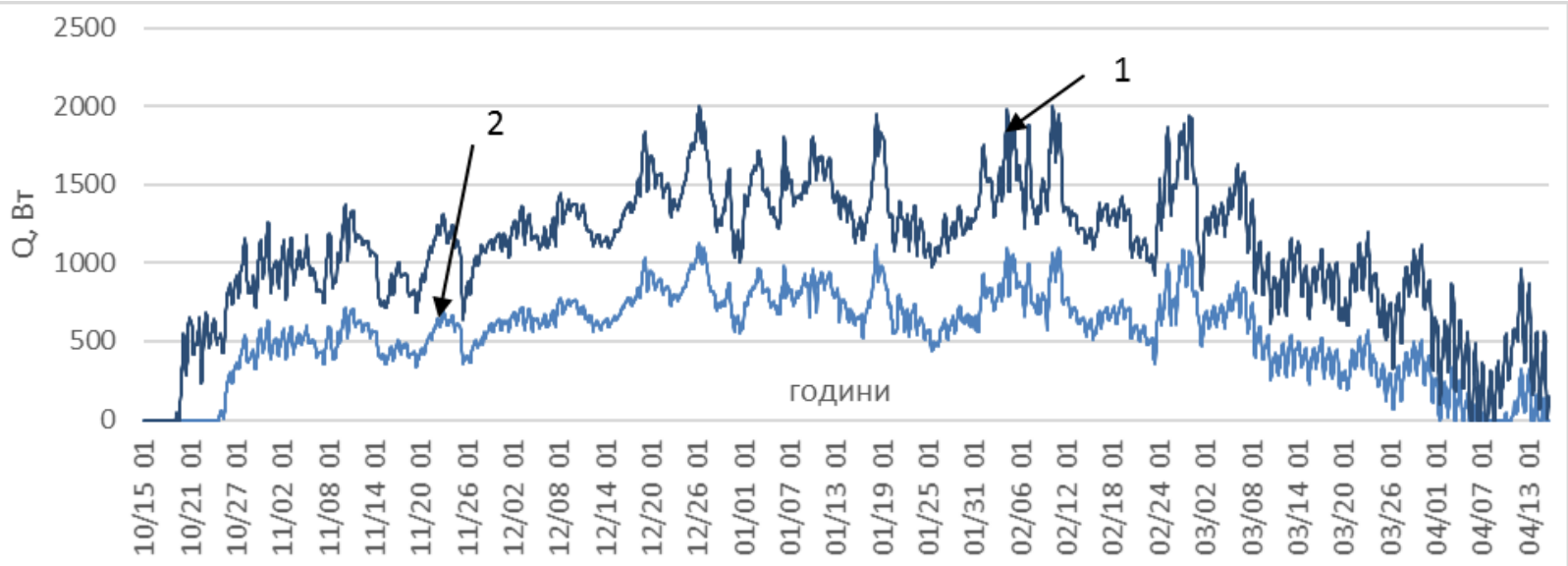

б)

\section{0}

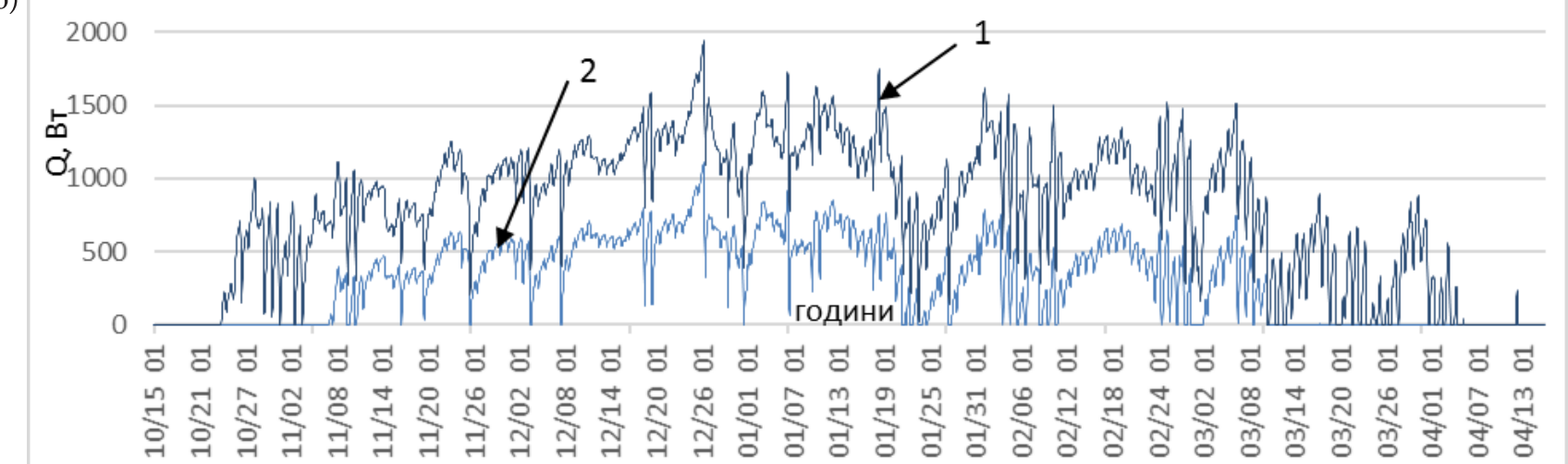

Рис. 5. Навантаження на систему опалення для опалювального періоду приміщення орієнтованого на північ (а) та південь (б): 1 - при нормативних значеннях кратності повітрообміну; 2 - при розрахованих (природна складова)

Для приміщень, орієнтованих на південь, коливання навантаження на систему опалення протягом доби дещо більші, на відміну від північної, що пояснюється сонячними теплонадходженнями в зону кімнати. Також в деякі дні спостерігаються короткострокові відключення опалення в пікові години сонячної активності.

\section{ВИСНОВКИ І ПЕРСПЕКТИВИ ПОДААЬ-} ШИХ ДОСАІДЖЕНЬ

1. На основі узагальненої методики [1822] та міжнародного кліматичного файлу IWEC [17] проведено погодинний розрахунок природної складової кратності повітрообміну. Визначено вплив на неї мінливості погодних умов (швидкість та напрям вітру, температура), зміни поверховості будівлі та поверху розташування кімнати. Значення природної кратності повітрообміну не перевищує 0,25год ${ }^{-1}$. Потрібно відмітити, що їі величина дещо більша для приміщень північної орієнтації, що обумовлено переважно північним напрямком вітру.

2. Створено динамічні сіткові моделі для дослідження енергетичного стану будівель на основі стандартів EN ISO 13790 [15] та EN ISO 13786 [16].

3. Встановлено, що енергопотреба будівлі при нормативному значенні кратності повітрообміну та розрахованому значенні природної складової кратності повітрообміну відрізняється до 50-75\%.

4. Для підтримання нормативного значення кратності повітрообміну при перебуванні ^юдей в приміщенні потрібно додатково використовувати провітрювання або механічну вентиляцію. Врахування фактичної природної кратності природного повітрообміну в приміщеннях змінної зайнятості уточнюе визначення рівня ефективності енергозберігаючих заходів 3 термомодернізації, а також визначає складову, що повинна забезпечуватися механічною вентиляцією, а отже i може бути утилізована в теплообмінниках рекуперативного типу. Дослідження динаміки впливу кратності повітрообміну на енергопотребу за цих умов потребує подальших досліджень. 


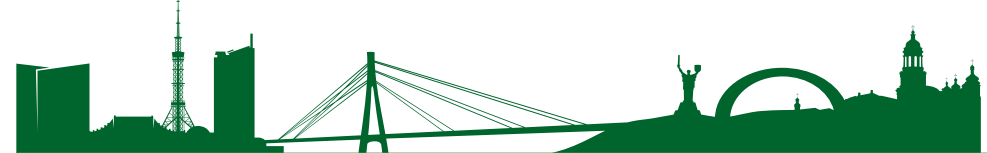

\section{БІБАІОГРАФІЧНИЙ СПИСОК}

1. Maslesa, I. E., Jensen P. A. \& Birkved, M. Indicators for quantifying Environmental Building Performance: A systematic literature review. J. of building engineering. 2018. Vol. 19. Pp. 552-560.

2. Bilous, I. Yu., Deshko V. I. \& Sukhodub I. O. Building inside air temperature parametric study. Magazine of Civil Engineering. 2016. Vol. 8. Pp. 65-75.

3. Mechouet, A., Mouhib, T., Balhamri, A. \& Ouali, E. M. Evaluating the impact of air infiltrations on the thermal and energy performances for different types of dwellings in casablanca city. International J. of Mechanical and Production Engineering Research and Development. 2018. Vol. 8. Pp. 793-800.

4. ДСТУ-Н Б В.3.2-3:2014 Настанова 3 виконання термомодернізації житлових будинків. - Чинний від 2015-10-01. - Київ: ДП «Укрархбудінформ», 2015. - 40 с.

5. Younes, C., Abishihid, C. \& Bitsuamlak, G. Air infiltration through building envelopes: a review. J. of Building Physics. 2011. Vol. 35-3. Pp. 267-302.

6. Білоус І. Ю. Оцінювання енергоефективності будівлі в умовах динамічної зміни характеристик середовища: автореф. дис. на здобуття наук. ступеня канд. тех. наук / І. Ю. Білоус. - Київ, 2019. - 20 с.

7. Kalamees, T. Air tightness and air leakages of new lightweight single-family detached houses in Estonia. Building and Environment. 2007. Vol. 42. Pp. 2369-2377.

8. Jokisalo, J., Kurnitski, J., Korpi, M., Kalamees, T. \& Vinha, J. Building leakage, infiltration, and energy performance analyses for finnish detached houses. Building and Environment. 2009. Vol. 44. Pp. 377-387.

9. Chen, S., Levine, M. D., Li, H., Yowargana, P. \& Xie, L. Measured air tightness performance of residential buildings in North China and its influence on district space heating energy use. Energy and Buildings. 2012. Vol. 51. Pp. 157-164.

10. Bilous, I., Deshko, V. \& Sukhodub, I. Parametric analysis of external and internal factors influence on building energy performance using non-linear multivariate regression models. J. of building engineering. 2018. Vol. 20. Pp. 327-336.

11. Leprince, V. \& Lyon, C. Les rencontres de l'Arcad, Etanchéité à l'air des enveloppes. 2011. Vol. 20.

12. Emmerich, S. J., Persily, A. K. \& Dowell, T. P. Impact of infiltration on heating and cooling loads in US office buildings. Proc. of the $26^{\text {th }}$ IEA Conf. of the Air Infiltration and Ventilation Center. 2005.
13. ДСТУ Б А.2.2-12:2015 Енергетична ефективність будівель. Метод розрахунку енергоспоживання при опаленні, охолодженні, вентиляції, освітленні та гарячому водопостачанні - Чинний від 2015.01.01. - Київ: ДП «Укрархбудінформ», 2015. - 140 c.

14. Bilous, I. Yu. \& Deshko, V. I. Mathematical models for determination of specific energy need for heating and cooling of the administrative building. Intern. J. of Engineering \& Technology. 2018. Vol. 7 (4.3). Pp. 325-330.

15. ДСТУ Б EN ISO 13790:2011 Енергоефективність будівель. Розрахунок енергоспоживання при опаленні та охолодженні (EN ISO 13790:2008, IDT) - Чинний від 01.01.2013. - Київ: ДП «Укрархбудінформ», 2011. - 229 с.

16. EN ISO 13786:2007 Thermal performance of building component - Dynamic thermal characteristics - Calculation methods. - CEN. European Committee for Standardization, 2007. 27 p.

17. Міжнародний кліматичний файл погоди IWEC для типового року: https://energyplus. net/weather-location/europe_wmo_region_6/ UKR//UKR Kiev.333450_IWEC.

18. Biler, A., Tavil, A. U., Su, Y. \& Kha, N. A Review of Performance Specifications and Studies of Trickle Vent. Buildings, 2018. Vol. 8. Pp. 152-183.

19. Berge A. Analysis of Methods to Calculate Air Infiltration for Use in Energy Calculations. Sweden 2011. 98 p.

20. ASHRAE Standard 62.2-2003 Ventilation and Acceptable Indoor Air Quality in Low-Rise Residential Buildings.

21. ASHRAE Fundamentals Handbook. 1997. P. 85.

22. ДСТУ Б В.2.2-19:2007 Будинки і споруди. Метод визначення повітропроникності огороджувальних конструкцій в натурних умовах. - Чинний від 2008-07-01. - Київ: ДП «Укрархбудінформ», 2008. - IV, 19 с.

\section{REFERENCES}

1. Maslesa, I. E., Jensen, P. A. \& Birkved, M. (2018). Indicators for quantifying Environmental Building Performance: A systematic literature review. J. of building engineering, Vol. 19, 552560 [in English].

2. Bilous, I. Yu., Deshko, V. I. \& Sukhodub, I. O. (2016). Building inside air temperature parametric study. Magazine of Civil Engineering, Vol. 8, 65-75 [in English].

3. Mechouet, A., Mouhib, T., Balhamri, A. \& Ouali, E. M. (2018). Evaluating the impact of air infiltrations on the thermal and energy 


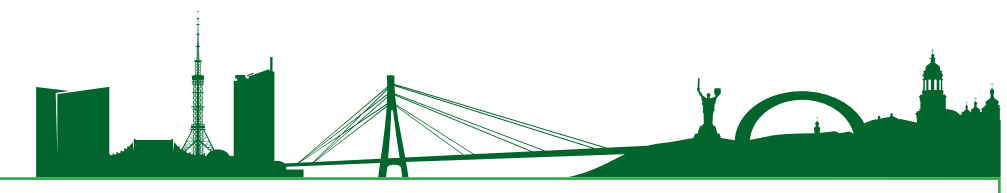

performances for different types of dwellings in Casablanca city. International J. of Mechanical and Production Engineering Research and Development, Vol. 8, 793-800 [in English].

4. Guidelines for the implementation of thermomodernisation of residential buildings. (2014). DSTU-H B V.3.2-3:2014 from 01 $1^{\text {st }}$ October 2015. K.: DP «Ukrarkhbudinform», 2015 [in Ukrainian].

5. Younes, C., Abishihid, C. \& Bitsuamlak, G. (2011). Air infiltration through building envelopes: a review. J. of Building Physics, Vol. 35-3, 267-302 [in English].

6. Bilous, I. Yu. (2019). Rating of building energy performance in the conditions of dynamic change of environmental characteristics. Extended abstract of candidate thesis. K. [in Ukrainian].

7. Kalamees, T. (2007). Air tightness and air leakages of new lightweight single-family detached houses in Estonia. Building and Environment, Vol. 42, 2369-2377 [in English].

8. Jokisalo, J., Kurnitski, J., Korpi, M., Kalamees, T. \& Vinha, J. (2009). Building leakage, infiltration, and energy performance analyses for finnish detached houses. Building and Environment, Vol. 44, 377-387 [in English].

9. Chen, S., Levine, M. D., Li, H., Yowargana, P. \& Xie, L. (2012). Measured air tightness performance of residential buildings in North China and its influence on district space heating energy use. Energy and Buildings, Vol. 51, 157-164 [in English].

10. Bilous, I., Deshko, V. \& Sukhodub, I. (2018). Parametric analysis of external and internal factors influence on building energy performance using non-linear multivariate regression models. J. of building engineering, Vol. 20, 327-336 [in English].

11. Leprince, V. \& Lyon, C. (2011). Les rencontres de l'Arcad, Etanchéité à l'air des enveloppes. Vol. 20 [in French].

12. Emmerich, S. J., Persily, A. K. \& Dowell, T. P. (2005). Impact of infiltration on heating and cooling loads in US office buildings. Proc. of the $26^{\text {th }}$ IEA Conf. of the Air Infiltration and Ventilation Center [in English].

13. Method for calculation of energy use for space heating, cooling, ventilation, lighting and domestic hot water (2015). DSTU B A.2.2-12:2015 from 01 ${ }^{\text {st }}$ January 2016. $\mathrm{K} .: \mathrm{DP}$ «Ukrarhbudinform» [in Ukrainian].

14. Bilous, I. Yu. \& Deshko, V. I. (2018). Mathematical models for determination of specific energy need for heating and cooling of the administrative building. Intern. J. of Engineering \& Technology, Vol. 7 (4.3), 325-330 [in English].

15. Energy performance of buildings - Calculation of energy use for space heating and cooling (2008). EN 13790:2008. CEN. European Committee for Standardization [in English].

16. Thermal performance of building component - Dynamic thermal characteristics - Calculation methods (2007). EN ISO 13786:2007. CEN. European Committee for Standardization, 2007 [in English].

17. International Weather for Energy Calculations. Retrieved from https:/energyplus.net/weatherlocation/europe_wmo_region_6/UKR//UKR_ Kiev.333450_IWĒC. [in English]

18. Biler, A., Tavil, A. U., Su, Y. \& Kha, N. (2018). A Review of Performance Specifications and Studies of Trickle Vent. Buildings. Vol. 8. [in English].

19. Berge, A. (2011). Analysis of Methods to Calculate Air Infiltration for Use in Energy Calculations. Göteborg: Chalmers University of Technology [in English].

20. ASHRAE Standard 62.2-2003 Ventilation and Acceptable Indoor Air Quality in Low-Rise Residential Buildings [in English].

21. ASHRAE Fundamentals Handbook. 1997. P. 85 [in English].

22. Method of determination of air permeability of envelope structures in field conditions (2015). DSTU B V.2.2-19:2007 from 01 ${ }^{\text {st }}$ July 2007. K.: $\mathrm{DP}$ «Ukrarhbudinform»[in Ukrainian].

Стаття надійшла до редакції 16.04.2019 р. 